\title{
ПОЛІЦЕЙСЬКИЙ НАГЛЯД ЗА ОСОБАМИ, ЗВІЛЬНЕНИМИ 3 МІСЦЬ ПОЗБАВЛЕННЯ ВОЛІ
}

Ярмакі Х. П., Ярмакі В. Х.

У статті надаються поняття та особливості поліцейського нагляду, досліджуються історичні аспекти запровадження та розвитку поліцейського нагляду в Європі, розглядається його співвідношення з адміністративним наглядом, аналізуються позиції науковців щодо визначення нагляду та його співвідношення з таким видом перевірочної діяльності, як контроль, розмежовується загальний поліцейський нагляд і спеціальний поліцейський нагляд за окремими категоріям громадян, які схильні до вчинення правопорушень. Особлива увага приділена еволюції нормативно-правового регулювання поліцейського нагляду за особами, звільненими з місць позбавлення волі, підставам та порядку встановлення, здійснення та припинення поліцейського нагляду за цією категорією осіб. Надана характеристика правилам нагляду, яких повинні дотримуватись піднаглядні та обмеженням, що встановлюються відносно піднаглядних.

Ключові слова: безпека, пробація, органи поліції, поліцейський, повноваження поліції, адміністративний нагляд, поліцейський нагляд, запобігання, правообмеження, превенція, спостереження, правова держава, превентивний нагляд, ресоціалізація.

В статье раскрываются понятие и особенности полицейского надзора, исследуются исторические аспекты возникновения и развития полицейского надзора в Европе, рассматриваєтся его соотношение с административным надзором, анализируются позиции ученых по вопросу определения понятия надзора и его соотношения с таким видом проверочной деятельности, как контроль, проводится разграничение общего полицейского надзора и специального полицейского надзора за отдельными категориями граждан, которые склонны к совершению правонарушений. Особенное внимание уделено эволюции нормативно-правового регулирования полицейского надзора за лицами, освобожденными из мест лишения свободы, основаниям и порядку установления, осуществления и прекращения полицейского надзора за данной категорией лиц. Представлена характеристика правил полицейского надзора, которые должны соблюдать поднадзорные, и ограничениям, устанавливаемых судом в отношении поднадзорных

Ключевые слова: безопасность, органы полиции, полицейский, полномочия полиции, полицейский надзор, правоограничения, предупреждение, превенция, правовое государство, наблюдение, превентивный надзор, ресоциализация.

It is provided the concept and features of police supervision; its correlation with administrative supervision is considered; the supervision of the behavior of previously convicted persons and legal acts regulating its implementation are analyzed. Given the central role of supervision in shaping police agency outcomes, the purpose of this paper is to understand ratings of supervisor performance overall and on several distinct dimensions. The description of the police as the strong arm of the State oversight reflects their authorization to enforce laws and policies defined by State institutions. It is concluded that there is a necessity to amend the Law of Ukraine "On the Administrative Supervision of Releases from Prison", other legal acts regulating the issue of supervision and probation.

The Institute for Administrative Supervision of National Police Authorities for persons' behavior released from imprisonment is personally policed by the police. In recent years in Ukraine, there has been a lively discussion between supporters of rigorous measures to combat crime and representatives of human rights organizations who believe that administrative supervision of persons released from imprisonment violates the constitutional rights of citizens. Meanwhile, when considering administrative supervision of persons released from imprisonment, from human rights perspective, one cannot but notice that by restricting the persons' rights who have committed serious crimes and are prone to their repetition, the Law thus directly protects rights and interests the right of obedient part of population, which is also the state's task.

In order to create an effective organizational and legal system of police supervision in Ukraine that would meet the standards of legal democratic state, it would be expedient to carry out in the future a detailed comparative legal analysis of police supervision in the European Union's states on the basis of which to make appropriate amendments to the laws of Ukraine "On Administrative Supervision for Releases from Prison", "On Probation"; to adopt a joint order of the Ministry of Internal Affairs of Ukraine and the Ministry of Justice of Ukraine on approval of the Instruction on the organization of administrative supervision of releases from prison by repealing the Instruction adopted in 2003 by the Ministry of Internal Affairs of Ukraine and the State Department of Ukraine for the Execution of Sentences, the latter was liquidated.

Key words: security, probation, police, police officer, police authority, administrative supervision, police supervision, prevention, restriction of law, supervision, legal state, preventive supervision, re-socialization.

Постановка проблеми та іï актуальність. Терористичні акти в усьому світі та в Україні послужили каталізатором процесу повсюдного переходу до так званого пріоритету колективної безпеки. Суть його полягає в тому, що заради забезпечення безпеки особи, суспільства та держави можливе часткове або повне обмеження прав і свобод окремих громадян. Об'єктивно це неминуче супроводжується процесом наділення поліцейських органів і спецслужб новими повноваженнями, пов'язаними з посиленням їх наглядової діяльності, розширенням сфери поліцейського нагляду. Незважаючи на об'єктивну зумовленість даних тенденцій, їх швидке поширення в світі, в тому числі в Україні, подібна ситуація викликає цілком виправдане занепокоєння насамперед з точки зору їі відповідності принципам правової держави. Разом з тим і сам термін «поліцейський нагляд» найбільш точно віддзеркалює суть посилення напрямів (види, форми, методи) діяльності правоохоронних органів, що використовува-

Ярмакі Х. П., Ярмакі В. Х., 2019 
лись і використовуються в українському законодавстві у теперішній час стає напівзабутим, а в «закордонному» слововживанні має сьогодні скоріше негативний відтінок. Такий стан, на наш погляд, потребує переосмислення та наповнення новим змістом.

Аналіз останніх досліджень і публікацій. Автори наукових праць 3 питань сучасного адміністративного нагляду i державного контролю відзначають наявні складності і протиріччя концептуальних основ їх розуміння, розмежування і реформування. Окремі науковці вважають, що існує тільки прокурорський нагляд, а адміністративний нагляд $\epsilon$ складовою державного контролю (О.Ф. Андрійко [1], В.М. Гаращук [3]). А, наприклад, Д.М. Бахрах [2], Х.П. Ярмакі [14], A.В. Денисова [4] вважають, що нагляд здійснює не тільки прокуратура, а й органи виконавчої влади, які наглядають, спостерігають за дотриманням правових та техніко-правових приписів як підпорядкованими, так і не підпорядкованими їм суб'єктами. Доводиться констатувати, що в теорії адміністративного права $\epsilon$ потреба у нових підходах до дослідження сучасних проблем зазначених інститутів взагалі та адміністративного нагляду за особами, звільненими з місць позбавлення волі, зокрема.

Метою статті $\epsilon$ - дослідження окремих аспектів поліцейського нагляду за особами, звільненими з місць позбавлення волі.

Виклад основного матеріалу. 3 прийняттям Закону України «Про Національну поліцію» у 2015 році [8] потрібна принципово інша платформа дослідження інституту поліцейського нагляду як спеціального адміністративного нагляду. При цьому поліцейський нагляд повинен набути такого змісту, який відповідав би загальновизнаним нормам міжнародного права, юридичним стандартам правової, демократичної держави, де права і свободи людини є найвищою цінністю, а держава їх гарантує та забезпечує.

Сучасне вітчизняне законодавство і думки провідних вчених свідчать, що адміністративний нагляд $\epsilon$ зовнішньо владною діяльністю компетентних адміністративних органів з проведення перевірок щодо дотримання фізичним особами та організаціями положень законів і підзаконних нормативних правових актів, що встановлюють вимоги до забезпечення різних видів публічної безпеки, незалежно від того, чи перебувають ці суб'єкти у сфері їх безпосереднього адміністративно-регулюючого впливу чи ні.

При цьому співробітники ряду таких органів (Національна поліція України, Державна прикордонна служба України, Служба правопорядку збройних сил України, Національна гвардія України, Служба безпеки України) мають право застосовувати спеціальні правові засоби заходи прямого (безпосереднього) примусу, що виражаються в затриманні, доставлянні фізичних осіб; здійсненні різного роду оглядів; застосуванні фізичної сили, спеціальних засобів, зброї і так далі. Зазвичай у структуру їх повноважень входить право проведення різноманітних оперативно-розшукових заходів, розшуку злочинців, що переховуються, та інших осіб. Очевидно, що в сукупності зазначені правові засоби головним чином спрямовані на протидію злочинності. Саме їх наявністю відповідні поліцейські органи, до яких можна віднести насамперед Нацполіцію, Прикордонну службу, Нацгвардію, Службу правопорядку
ЗСУ, СБУ, і відрізняються від інших державних органів, що беруть участь у боротьбі із злочинами. Слід також брати до уваги спеціальні об'єкти поліцейського нагляду, наприклад, спеціально встановлений державою режим обігу наркотичних і психотропних засобів, зброї та боєприпасів; відомостей, що становлять державну таємницю, спеціальних технічних засобів, призначених для негласного отримання інформації; поведінка осіб, потенційно небезпечних для суспільства. До перерахованого можна також віднести і більш широкі об'єкти громадські порядок і безпеку.

Особливо слід виділити осіб, що представляють потенційну суспільну небезпеку. Насамперед це особи, звільнені з місць позбавлення волі, а також умовно засуджені і засуджені до покарань, не пов'язаних з позбавленням волі. Крім них, такими об'єктами можуть виступати особи, що мають нездорову психіку, схильні до скоєння певного роду злочинів, хворі на наркоманію або хронічний алкоголізм, які ведуть асоціальний спосіб життя; окремі категорії неповнолітніх; власники джерел підвищеної небезпеки, для яких передбачені спеціальні ліцензійно-дозвільні методи нагляду. У цьому разі об'єктом нагляду $є$ люди (точніше, їх поведінка), що надає нагляду особливі властивості. Персоніфікований нагляд може бути тільки поліцейським, загальний адміністративний нагляд щодо таких людей не здійснюється.

Зауважимо, що правовою основою поліцейського нагляду рівною мірою служать як кримінальне (нагляд за особами, засудженими до покарань, не пов'язаних з позбавленням волі), так і адміністративне законодавство, на відміну від загального адміністративного нагляду, що здійснюється шляхом спостереження за дотриманням (виконанням) лише адміністративного законодавства та перевірки дотримання техніко-правових приписів, які теж базуються на адміністративному законодавстві.

Дані особливості дозволяють виділити з адміністративного нагляду самостійний вид - поліцейський нагляд і відмежувати його від загального адміністративного нагляду, який, на нашу думку, є найбільш поширеним видом нагляду. Необхідно зауважити, що поліцейський нагляд, будучи видом адміністративного нагляду, на противагу іншому його різновиду (загальний адміністративний нагляд), може бути визначений і як спеціальний адміністративний нагляд.

Інститут адміністративного нагляду органів Національної поліції за поведінкою осіб, звільнених з місць позбавлення волі, $\epsilon$ персоніфікованим поліцейським наглядом. В останні роки в Україні проходить жвава дискусія між прибічниками жорстких заходів боротьби зі злочинністю та представниками правозахисних організацій, які вважають, що адміністративний нагляд за особами, звільненими з місць позбавлення волі, порушує конституційні права громадян. Тим часом, розглядаючи адміністративний нагляд за особами, звільненими з місць позбавлення волі, з правозахисної точки зору, не можна не помітити, що, обмежуючи права осіб, які вчинили тяжкі злочини і $є$ схильними до їх повторення, зазначений Закон тим самим безпосередньо захищає права й інтереси правослухняної частини населення, що також $\epsilon$ завданням держави. Прикладом тут може бути поліція Ізраїлю, яка займається охороною громадського порядку, ліквідацією злочинності, наглядом 
за дотриманням законодавства. Уведений у 2012 році Урядом Ізраїлю план «Поворот», крім інших завдань поліції, передбачив підвищення рівня обслуговування законослухняних громадян. Одним з чинників, якій сприяє реалізації зазначеного у плані завдання, $\epsilon$ здійснення поліцією адміністративного нагляду за окремими категоріями громадян, схильних до вчинення злочинів, відносно яких судом встановлено окремі обмеження їх прав і свобод. Здійснення поліцейського нагляду зменшують можливості піднаглядних осіб вчиняти правопорушення, у тому числі порушення прав і свобод людини та громадянина.

Зауважимо, що подібний підхід (обмеження прав і свобод певної категорії правопорушників) характерний для більшості зарубіжних держав, в тому числі країн з розвиненою демократичною системою. У таких державах, як Бельгія, Німеччина, Данія, Франція, Швеція, Японія, існують інститути пробації, а також розвинені більшою чи меншою мірою інститути адміністративного (в тому числі поліцейського) нагляду. США мають одну з найсуворіших систем пробації та пост пенітенціарного нагляду у світі.

У законодавстві Німеччини Поліцейський нагляд (Polizeiaufsicht) за злочинцями став застосовуватися ще в кінці XVIII ст. Вже тоді існувала думка, що необхідні додаткові запобіжні заходи щодо захисту суспільства від соціально небезпечних осіб, і особливо тих, хто після відбуття покарання знову може вчинити злочин. Вперше поліцейський нагляд як додаткове покарання був згаданийв 1787р. уКримінальномукодексі імператораЙосифа II, де поліції ставилося в обов'язок вести контроль за поведінкою винних після відбуття ними покарання.

Надалі інститут поліцейського нагляду та порядок його застосування змінювався. В кінці 60-х років 20 сторіччя в Німеччині поліцейський нагляд був скасований i введений адміністративний нагляд органів юстиції за поведінкою засуджених осіб, який більшою мірою відповідає Конституції Німеччини і принципам побудови правової держави.

Відповідно до ст. 64 Конституції України конституційні права і свободи не можуть бути обмежені, крім випадків, чітко передбачених Конституцією України. До таких випадків належать обмеження, що встановлюються відносно окремих категорій засуджених, звільнених з місць позбавлення волі, зокрема:

а) засуджених до позбавлення волі за тяжкі, особливо тяжкі злочини або засуджених два і більше разів до позбавлення волі за умисні злочини, якщо під час відбування покарання їх поведінка свідчила, що вони вперто не бажають стати на шлях виправлення і залишаються небезпечними для суспільства;

б) засуджених до позбавлення волі за тяжкі, особливо тяжкі злочини або засуджених два і більше разів до позбавлення волі за умисні злочини, якщо вони після відбування покарання або умовно-дострокового звільнення від відбування покарання, незважаючи на попередження органів внутрішніх справ, систематично порушують громадський порядок і права інших громадян, вчиняють інші правопорушення;

в) засуджених до позбавлення волі за один із злочинів, пов'язаних з незаконним обігом наркотичних засобів, психотропних речовин і прекурсорів [7]

Адміністративний нагляд за особами, звільненими з місць позбавлення волі, в Україні має давню історію, він існував у роки, коли Україна знаходилась у складі російській імперії, та в роки існування радянського союзу. Умови адміністративного нагляду та процедури його здійснення поступово з роками пом'якшувались.

Сьогодні порядок прийняття рішення про встановлення нагляду та компетенція по його встановленню урегульовані окремим законодавчим актом Законом України «Про адміністративний нагляд за особами, звільненими з місць позбавлення волі» від 01.12.1994 №264/94-ВР (зі змінами, відповідно ЗУ від 23 грудня 2015 року N 901-VIII), а також Законом України «Про Національну поліцію» від 02.07.2015 № 580-VIII [8].

Зазначений нагляд має примусовий та профілактичний характер. Статтею 1 Закону України «Про адміністративний нагляд за особами, звільненими з місць позбавлення волі» від 01.12.1994 №264/94-ВР визначено вказаний вид адміністративного нагляду як систему тимчасових примусових профілактичних заходів спостереження і контролю за поведінкою окремих осіб, звільнених з місць позбавлення волі, що здійснюється органами Національної поліції.

Останнім часом щодо правової природи адміністративного нагляду за особами, звільненими з місць позбавлення волі, в адміністративно-правовій літературі відсутня єдність поглядів. За радянських часів, коли цей нагляд і встановлювався, і здійснювався міліцією, запитань щодо нього практично не виникало. В наш же час, особливо після того, як адміністративний нагляд почав застосовуватися в судовому порядку, в літературі все частіше висловлюються міркування про необхідність перегляду адміністративно-правового характеру цього заходу, оскільки об'єкт правового регулювання в цьому випадку не відповідає галузевій приналежності норм, за допомогою яких він здійснюється [11]. Певна доля істини в цьому твердженні $\epsilon$, але не можна погодитись з тим, що об'єкт правового регулювання тут не $\epsilon$ адміністративно-правовим. Ми тут цілком погоджуємося із А.Т. Комзюком, який зазначає, що «заходи адміністративного примусу, яким $є$ і адміністративний нагляд, можуть застосовуватись для боротьби зі злочинами шляхом їх попередження і припинення, а деякі з них саме для цього і використовуються». Таким чином, можна зробити висновок, що нагляд за особами, звільненими з місць позбавлення волі, не $є$ суто адміністративним, а має комплексний, а отже - міжгалузевий характер, оскільки він встановлюється, продовжується і припиняється судом, і тільки суд притягує до відповідальності піднаглядних, які порушили правила нагляду, а поліція здійснює нагляд за дотриманням піднаглядними встановлених правил та обмежень, здійснює виховний вплив на них, документує факти порушення ними Закону.

Більшість вітчизняних адміністративістів називає адміністративний нагляд за особами, звільненими 3 місць позбавлення волі, адміністративно-запобіжним заходом, проте в ряді випадків його відносять до заходів адміністративного припинення [6]. На думку автора, адміністративний нагляд за особами, звільненими з місць позбавлення волі, $є$ винятково запобіжним заходом, тому що головною метою його $\epsilon$ запобігання вчиненню піднаглядним нових правопорушень. Таку ж позицію займає і законодавець, оскільки в ст. 2 Закону «Про адміністративний нагляд за особами, звільненими з місць позбавлення волі» зазначено, що адміністратив- 
ний нагляд встановлюється з метою запобігання вчиненню злочинів окремими особами, звільненими з місць позбавлення волі, і здійснення виховного впливу на них [7]. Словосполучення «запобігання вчиненню злочинів» доцільно замінити на «запобігання вчиненню правопорушень», оскільки систематичне порушення громадського порядку, прав інших громадян, вчинення інших правопорушень (п. «в» ст.3 Закону «Про адміністративний нагляд за особами, звільненими з місць позбавлення волі») $\epsilon$ приводом для встановлення адміністративного нагляду. Крім того, ст. 2 Закону «Завдання адміністративного нагляду» необхідно доповнити і такими: 1) перевиховання засуджених у дусі чесного ставлення до праці, дотримання норм законів та правил співжиття; 2) ресоціалізація та соціальна адаптація засуджених.

Отже, головне завдання адміністративного нагляду за особами, звільненими з місць позбавлення волі, полягає у їх ресоціалізації та соціальній адаптації. Так, під ресоціалізацією ст. 6 Кримінально-виконавчого кодексу України розуміється свідоме відновлення засудженого в соціальному статусі повноправного члена суспільства; повернення його до самостійного загальноприйнятого соціально-нормативного життя в суспільстві. Необхідно зазначити і те, що питання ресоціалізації сьогодні залишається дискусійним. Наприклад, M.І. Бажанов та В.М. Трубников виправлення злочинців вважають практично неможливим, оскільки до людини застосовуються певні обмеження і вона утримується у становищі, де кожен крок $є$ регламентованим, що розвиває пасивність [5].

На думку автора, ресоціалізація осіб, звільнених з місць позбавлення волі, буде мати позитивний ефект тільки за умови вірно побудованого виховного процесу, загальної та індивідуальної роботи із цією категорією осіб, а також ефективно здійснюваного нагляду за їх поведінкою.

Своєю чергою соціальна адаптація - це комплекс правових, економічних, організаційних, соціально-психологічних та інших заходів, які здійснюються щодо звільнених осіб з метою пристосування до умов соціального середовища, захисту їх прав і законних інтересів.

Як зазначено в ст. 7 Закону «Про адміністративний нагляд за особами, звільненими з місць позбавлення волі», адміністративний нагляд здійснюється поліцією. Поліцейські беруть на облік осіб, щодо яких встановлено адміністративний нагляд, фотографують, а у разі необхідності у них беруть відбитки пальців. Поліцейські зобов'язані систематично контролювати поведінку цих осіб, запобігати порушенням ними громадського порядку та прав інших громадян і припиняти їх, проводити розшук осіб, які уникають адміністративного нагляду.

Оскільки адміністративний нагляд становить систему тимчасових примусових профілактичних заходів із спостереження та контролю за поведінкою зазначених осіб, зупинимось детальніше на обов'язках піднаглядних та обмеженнях для них, в забезпеченні виконання яких поліцією і полягає зміст цього нагляду.

Насамперед Закон України «Про адміністративний нагляд за особами, звільненими з місць позбавлення волі» визначає обов'язки піднаглядних щодо ведення законослухняного способу життя, дотримання громадського порядку і прав громадян. 3 цією метою вони зобов'язані: прибути у визначений установою вико- нання покарань термін в обране ними місце проживання і зареєструватися в органі поліції; з'являтися за викликом поліції у вказаний термін і давати усні та письмові пояснення 3 питань, пов'язаних 3 виконанням правил адміністративного нагляду; повідомляти поліцейських, які здійснюють адміністративний нагляд, про зміну місця роботи чи проживання, а також про виїзд за межі району (міста) у службових справах; в разі від'їзду в особистих справах з дозволу поліції в інший населений пункт та перебування там більше доби зареєструватися в місцевому органі поліції [7].

Піднаглядний повинен додержуватись також ряду обмежень, встановлених щодо нього постановою судді. Це можуть бути: заборона виходу з будинку, квартири у визначений час, який не може перевищувати восьми годин на добу; заборона перебування у визначених місцях району (міста); заборона виїзду чи обмеження часу виїзду в особистих справах за межі району (міста); обов'язок з'являтися в поліцію від одного до чотирьох разів на місяць для реєстрації. Обмеження можуть встановлюватися, з урахуванням особи та поведінки піднаглядного, характеру вчинених ним у минулому злочинів, способу його життя, сімейного стану, кола знайомих тощо, як у повному обсязі, так і частково. Слід наголосити на тому, що інші обмеження, крім зазначених в Законі, встановлюватися не можуть, тобто цей перелік $\epsilon$ вичерпним [12].

Так, заборона виходу з будинку, квартири у визначений час полягає в тому, що піднаглядний зобов'язаний протягом встановленого йому часу (не більше восьми годин підряд) невідлучно перебувати у будинку (квартирі) за місцем постійного проживання. Час такої заборони має обиратися таким чином, щоб виключити вільне пересування особи в години доби, найбільше придатні для вчинення правопорушень, і навпаки, створити додаткові можливості для позитивного впливу на піднаглядну особу членів сім'ї, рідних, представників громадськості тощо. Зрозуміло, що заборону залишати будинок (квартиру) для піднаглядного слід встановлювати на час, вільний від роботи чи навчання в закладі освіти, і не включати час, необхідний для поїздки і повернення з роботи чи навчання. У разі проживання особи у багатоквартирному будинку вважається, що в цей час особа має перебувати саме в квартирі, в якій вона постійно проживає. Якщо піднаглядний проживає у будинку на праві приватної власності, то в поняття «будинок» включається і присадибна ділянка з господарськими будівлями. На практиці, звичайно, не визнається порушенням, якщо піднаглядний на момент перевірки перебуває безпосередньо біля входу в будинок (під'їзд, квартиру), в якому постійно проживає. Зазвичай піднаглядному забороняється вихід з дому (квартири) в більшості випадків з 22.00 до 6.00 годин. Вважаємо, що в зимові місяці, коли темніє рано, піднаглядному слід забороняти вихід дещо раніше, при цьому враховувати змінність роботи піднаглядного або час його навчання [12].

Заборона перебування у визначених місцях району (міста) ґрунтується на особливостях антигромадської поведінки піднаглядного в минулому або ж одержаній інформації про можливу кримінальну поведінку в майбутньому. Сутність цього обмеження полягає у тому, що у піднаглядного зменшується можливість здійснювати негативний вплив на інших, схильних до правопору- 


\section{Правове забезпечення адміністративної реформи}

шень громадян, підтримувати старі та встановлювати нові злочинні зв'язки. У постанові про встановлення обмежень особі мають бути перераховані і конкретно названі всі пункти, де заборонено перебувати піднаглядному, що дозволить уникнути як випадкових помилок з їі боку, так і посилання в разі порушення на незнання змісту заборони [13].

Заборона виїзду чи обмеження часу виїзду в особистих справах за межі району (міста) означає, що виїзд піднаглядного за межі адміністративного району або за межі міста не дозволяється без особливого на те дозволу, наданого органом поліції. Варто зауважити, що забороняється виїзд тільки в особистих справах, тому виїзд у відрядження під це обмеження не підпадає.

В разі зміни особою, яка перебуває під адміністративним наглядом, постійного місця проживання дільничний офіцер поліції, який здійснює нагляд, повідомляє про це міськрайвідділ за новим місцем проживання піднаглядного.

Явка піднаглядного в поліцію для реєстрації може бути передбачена від одного до чотирьох разів на місяць. Для явки мають призначатися конкретні дні місяця, які завчасно під розписку оголошуються піднаглядному.

Примусові заходи, що застосовуються до піднаглядного, повинні поєднуватися із наданням соціальної та правової допомоги, вихованням і роз'яснювальною роботою, як поліцейськими, так і працівниками служби пробації. Значення адміністративного нагляду за особами, звільненими з місць позбавлення волі, полягає у тому, що він: по-перше, $\epsilon$ заходом попередження та припинення правопорушень, розшуку піднаглядних; по-друге, становить комплекс правових, економічних, організаційних, соціально-психологічних та інших заходів, які здійснюються щодо звільнених осіб з метою пристосування останніх до умов соціального середовища, захисту їх прав і законних інтересів; по-третє, під час його здійснення вирішуються питання щодо працевлаштування, професійної орієнтації (переорієнтації) та перепідготовки, створення належних житлово-побутових умов.

Висновки. Таким чином, можна стверджувати, що адміністративний нагляд за особами, звільненими з місць позбавлення волі, $\epsilon$ важливим видом заходів адміністративного примусу, які у першу чергу застосовуються поліцією, тому такий нагляд можна вважати «поліцейським наглядом».

Інститут поліцейського (адміністративного) нагляду в окремих проміжках часу вважався малоефективним та таким, що у правоохоронній практиці не має важливого значення. Оскільки поліцейський нагляд значною мірою обмежував права і свободи громадян, він був предметом жорстких дискусій і в окремі періоди мав більше супротивників, ніж прихильників.

Відомий у XVIII столітті як засіб контролю поліції за поведінкою винних після відбуття ними кримінального покарання він удосконалювався, видозмінювався і навіть відмінявся у деяких державах, щоб через деякий час знову відродитися (Німеччина, Біларусь, Казахстан, Росія тощо).

На підставі аналізу практики здійснення поліцейського нагляду та нормативно-правових актів, що його регламентують, робиться висновок щодо необхідності створення в Україні ефективної організаційно-правової системи поліцейського нагляду, який відповідав би стандартам правової демократичної держави. Доціль- ним було б у подальшому здійснити детальний порівняльно-правовий аналіз поліцейського нагляду у державах СНД та Європейського Союзу, на підставі якого внести відповідні зміни до законів України «Про адміністративний нагляд за особами, звільненими з місць позбавлення волі», «Про пробацію»; прийняти спільний наказ MBC України та Мінюсту України щодо затвердження Інструкції про організацію здійснення адміністративного нагляду за особами, звільненими з місць позбавлення волі, скасувавши чинну Інструкцію, що була прийнята у 2003 році МВС України та Державним Департаментом України з виконання покарань.

\section{Література}

1. Андрійко О.Ф. Державний контроль в Україні: організаційно-правові засади : монографія. Київ : «Наук. Думка», 2004. 300 с.

2. Бахрах Д.Н. Важные вопросы науки административного права. Государство и право. 1993. № 2. С. 32-43.

3. Гаращук В.М. Теоретико-правові проблеми контролю та нагляду у державному управлінні : автореф. дис. ... на здобуття наук. ступеня доктора юридичних наук : спец. 12.00.07 - теорія управління; адміністративне право і процес; фінансове право ; Національна юридична академія України ім. Ярослава Мудрого. Харків, 2003. 35 с.

4. Денисова А.В. До питання про особливості адміністративного нагляду органів виконавчої влади у екологічній сфері. Прикарпатський юридичний вісник. 2017. Випуск № 3(18). С. 53-56.

5. Кримінальне право України. Загальна частина : підручник для юрид. вузів і фак. / М.І. Бажанов, Ю.В. Баулін, В.І. Борисов та ін. ; За ред. професорів М.І. Бажанова, В.В. Сташиса, В.Я. Тація. Харків : Право, 1997. С. 188.

6. Мельник І.В. Застосування заходів адміністративного примусу в умовах розбудови правової держави : дис. ... канд. юрид. наук: 12.00.07. Київ, 2004. 186 с.

7. Про адміністративний нагляд за особами, звільненими з місць позбавлення волі: Закон України від 01.12.1994 №264/94-ВР. Відомості Верховної Ради України. 1994, N 52 (27.12.94), ст. 455.

8. Про Національну поліцію: Закон України від 02.07.2015 № 580-VIII. Відомості Верховної Ради України. 2015, N 40-41 (09.10.2015), ст. 379

9. Про пробацію: Закон України від 5.02 .2015 р. № 160-VIII. Відомості Верховної Ради України. 2015. № 13. Ст. 93.

10. Соловей Ю.П. Правовое регулирование деятельности милиции в Российской Федерации : дисс. ... докт. юрид. наук. Марина, 1993. 346 с.

11. Трубников В.М. Кримінально-виконавче право України. Харків : Право, 2001. 375

12. Ярмакі Х.П. Адміністративно-наглядова діяльність міліції в Україні: Монографія. Одеса : Юридична літератуpa, 2006. С. 147.

13. Ярмакі Х.П. Адміністративно-наглядова діяльність міліції в Україні: автореф. дис.д.ю.н.12.00.07. Харківськ. нац. ун-т внутр. справ. Харків, 2007. С. 14.

Ярмакі Х. П., доктор юридичних наук, професор, професор кафедри адміністративного права та адміністративного процесу

Одеського державного університету внутрішніх справ

Ярмакі В. Х., кандидат юридичних наук, доцент, доцент кафедри конституційного та міжнародного права

Одеського державного університету внутрішніх справ 